\title{
Remembering Tom: The Gay Games' Ego Ideal and Ideal Ego ${ }^{1}$
}

\author{
JUDY DAVIDSON
}

$\|$

Judy Davidson is an Assistant Professor in the Faculty of Physical Education and Recreation at the University of Alberta. Her interests include feminist and queer theory, cultural studies, and critical sport and leisure studies.

The Gay Games and Cultural Events have become recognized as the premiere international athletic event supportive of lesbian, gay, bisexual, and transgendered individuals. The multi-day spectacle emulates the modern day Olympics in size and grandeur. The Gay Games' founding vision was to provide opportunities where "athletes could openly celebrate both their athletic and sexual identities in ways not currently possible in most mainstream sporting events" (Griffin 190). The first of these quadrennial Games was held in 1982 and they have since become major cultural and athletic events.

As might seem appropriate, San Francisco was the site for the first two games (in 1982 and 1986) and Celebration ' 90 was staged in Vancouver. These Games were the largest sporting event of their

${ }^{1}$ I am grateful to jan jagodzinski for suggesting early in my doctoral research that I work through the idea of Tom Waddell as mediator between ego ideal and ideal ego. I am indebted to Michelle Helstein for helping me understand these concepts, particularly our discussions about Slavoj Zizek's ideas. Doug Aoki deserves special mention for insistently terrorizing me with psychoanalytic theory. This paper is part of my doctoral dissertation (Davidson, 2003) which was funded in part by a Social Sciences and Humanities Research Council Doctoral Fellowship. This Gay Games project would not have been possible without the Gay Games archive collection at the San Francisco Public Library and I thank the helpful staff there during my data collection in October, 2000 and February 2001. I would also like to acknowledge the helpful suggestions and careful, sustained readings by two anonymous reviewers and the guest editor for this issue, Sharon Rosenberg. 
kind held in the world that year. New York City hosted Unity '94, which marked the 25th Anniversary of the Stonewall Riots (often heralded as the "birth" of the gay rights movement). Over ten thousand people participated in 1994. Gay Games V were held in Amsterdam in August, 1998. Fifteen thousand athletes competed in 30 events in the Netherlands with 250,000 spectators involved in cheering them on. Gay Games VI were hosted in Sydney, Australia in November 2002, using the Homebush Olympic Park for many of the events. The Federation of Gay Games (FGG) is the international governing body for this organisation which claims to be the most inclusive major sporting event in the world (Davidson 15-16).

Dr. Tom Waddell, founder of the Gay Games, deeply imbued the event with a certain sense of Olympism. In order to provide an "Olympic" experience for gay and lesbian athletes, this charismatic medical doctor and former US Olympic track athlete, organized the first Gay Olympic Games in 1982. Waddell fervently believed in the "higher" ideals of Olympism (often figured as education, equal opportunity, fair play, excellence, and international goodwill) and wanted his Gay Olympics to embody those virtues (Segrave 150).

Waddell indvidualized the pursuit of excellence through athletics to become the mainstay mantra of the Gay Games, exhorting gay and lesbian athletes to excel "despite" their sexuality. His oft-quoted statement "To do one's best is the ultimate goal of human achievement" has been used liberally in subsequent Gay Games promotions (Waddell in Labrecque i). Waddell hoped that the ideals of Olympism would transcend the petty squabbling of the scandalridden "real" Olympics so true athletic competition could thrive. Athletes from around the world paraded behind city team signs in highly regulated uniforms (no corporate advertising, no Olympic logos) at highly choreographed opening and closing ceremonies (Athlete's package 1; Herkenhoff \& Lewinstein 1). Athletic events were organised according to set rules and regulations with teams competing and crowds available for cheerleading. Medal ceremonies were ritual affairs. Waddell endeavoured to combine the allure of the Olympics with the beauty of sport in a vibrant gay community (Davidson 61).

Despite these Olympic emulations, the Gay Games suffered many losses in their first five years. In 1982, a court injunction stopped the event from calling itself the Gay Olympics at the 


\section{8 / J. Davidson}

insistence of the powerful United States Olympic Committee (USOC). In the summer of 1987, the US Supreme Court made permanent the ban on the word "Olympic," and, three weeks after this judicial decision, the visionary founder, Waddell, died of AIDSrelated causes (Davidson 49-75). Waddell directed not only the guiding philosophy and principles of the Gay Games, but through his death-and how his death has been remembered-imprinted them permanently in and on the organization. His liberal notion of gay pride is one of the strongest pulls for the success of the Gay Games.

In grief, the Gay Games organization and members of the gay community who identified with the Gay Games cause made attempts to vindicate their Olympic loss. In 1987 and 1988 a grassroots protest targeted the Visa credit card company. Supporters of the Gay Games were encouraged to boycott Visa because of a default sponsorship program of the USOC. Waddell's memory was regularly invoked. In 1988, a divisive battle in San Francisco erupted over the Bay Area's bid to host the 1996 Summer Olympics. Certain municipal politicians, including the mayor of San Francisco, insisted that the USOC agree to several anti-homophobia measures before SF would agree to bid for the games. Again the figure of Waddell was repeatedly used to bolster the case (Davidson, 82-97). After these (relatively fruitless) protests, the discourse of resisting the Olympics fell away and Tom Waddell became memorialized in various ways through the Gay Games. A trophy in his honour, commemorative coins, panels on the AIDS quilt, and video tributes have all functioned symbolically to keep his memory alive (Davidson 100-108).

In this paper, I focus on how the Gay Games' community has consciously memorialized Waddell, and, simultaneously, how his figure insistently psychically governs gay pride discourse through the melancholic loss of the word Olympic and Waddell himself. I will argue that the prohibitions and losses suffered by the Gay Games and Tom Waddell have had profound psychic effects in securing the success and viability of subsequent stagings of the events and the establishment of the Gay Games movement. The first half of the paper describes how some of the memorial practices and objects have evolved. The second half asks us to consider whether in fact these kinds of remembrances by the Gay Games community are actually a "successful" kind of mourning. I que(e)ry how the figure of Tom Waddell continues to pyschically keep intact the injurious 
homophobic interpellation through which both the ideal ego and ego ideal for the Gay Games emerged. Judith Butler (1990; 1997) suggests that all subjects are necessarily produced through melancholia. In the end, the manifest attempts to mourn Waddell may only be the preconditions for a melancholic incorporation. Remembering the man whose gay pride mission defined the Gay Games enterprise may only continue to solidify the homophobic shame that inaugurates the event. This argument points to questioning the effectiveness, at the productively psychic level, of certain lesbian and gay memorial practices, suggesting that they may in fact simply reiterate and keep intact the original homophobic loss.

\section{Remembering Tom}

On July 11, 1987, Dr. Thomas Flubacher Waddell died at home from AIDS-related complications. He had voluntarily removed himself from all pain medication 36 hours prior to his death. Saying, "This should be interesting," he never spoke again, and slipped into his final coma. In his last weeks, family and friends surrounded and supported the dying hero (Waddell \& Schaap 4). Waddell had been showcased extensively in the last year of his life, notably since he had "come out" with his AIDS diagnosis. Two major network television pieces were produced on his life, several articles appeared in the San Francisco Chronicle, and a biography was in process (Fernandez B5; Mandel 1987 B3; Scheer 33). Waddell also received many community awards, most notably the Harvey Milk Community Service Award presented by then San Francisco Mayor Diane Feinstein in March 1987 (Fernandez B5; Marcus 32). Ten days before his death, a banner reading "Gay Olympians Salute Tom Waddell" was carried in the San Francisco Gay Pride March ("A salute" 14). And Springfield College, the ultraconservative athletic school Waddell had attended, awarded him an honorary doctorate, posthumously, after the student body petitioned the administration following a special about Waddell shown on ABC's news documentary television show 20/20 (Moor 41).

In death, and even before his imminent passing, Tom Waddell was immortalised as a hero, represented as a unique and truly amazing human being. His good works as a medical doctor, tireless advocate for "minorities," and pugnacious fighter for human rights and social justice granted him the epitaph of healer-not only of the 
body but of the human spirit as well. The public eulogies for him poured in as his death was announced. According to his adherents, Waddell "was able to set the imagination and the hearts of a community on fire with enthusiasm and with purpose" (White 1987a, 23). Tom Waddell

had everything. He was brilliant, loving, handsome, strong, successful and popular...His message was always hope, optimism, love and struggle towards the light... [Waddell's] greatest gift was his spirit, his tenacity, his love, and his dedication...In his lifetime, [he] created such a beacon of goodness in this world that its light will always illuminate [our] path (Mandel 1987, B3).

One week after his death, the city of San Francisco honoured Waddell with a public tribute organised by its Department of Public Health at which over four hundred people gathered in the rotunda of the majestic San Francisco City Hall. It was the first time since 1978, when the openly gay politician Harvey Milk was assassinated on the front steps of the same City Hall, that a non-elected (and, as it happened, homosexual) individual was so honoured officially by the city (Brazil B1; White 1987a). Waddell's wife, ${ }^{2}$ Sara Lewinstein, announced to thunderous applause that the lien on Waddell's home had been lifted by the USOC, and that the Olympic organisation would not seek monetary damages from anyone who had been involved with the Gay Games (Brazil B8; "They Stole a Word" 6). Many individuals in the crowd wore their Team San Francisco uniforms from Gay Games I or II. Gay Olympics t-shirts, which had escaped the hurried censorship just prior to the first Games, were proudly worn. One attendee pronounced, "I wanted to yell 'Olympics' at the top of my voice" (White 1987b, 13).

In spite (or because) of the overdetermination of Waddell with the Gay Games, the print media coverage of his death reinscribed a "normalised" and heteromasculine hero. This held true especially

2 Tom Waddell and Sara Lewinstein met organising Gay Games I. They were good friends and both had a desire to raise a child. In 1983, Jessica Waddell Lewinstein was born. It wasn't until after Waddell was diagnosed with AIDS in 1984 that the self-identified gay man and lesbian decided to get married to legally protect Jessica in the event of Waddell's death. They each were involved in same-sex relationships while sharing the parenting of Jessica (Waddell \& Schaap). 
for the San Francisco Chronicle's content but included the BAR's ${ }^{3}$ reportage as well. This effect was subtly produced through two particular representations of a dying, and finally a dead, Waddell, over and above his contribution to the creation and production of the Gay Games. The first of these invoked him as a decathlete, and reminded readers that the decathlon was considered to be the ultimate athletic test within serious sporting circles. In the second representational strategy, Waddell was heteronormatively produced through the invocations of his wife and child. Let me speak to each briefly.

Waddell was called up as being the sixth greatest athlete in the world in 1968. His strength and skill were invoked repeatedly, even though AIDS had ravaged his once powerful body (Fernandez B1; Schaap 1987 28, 31; Scheer 33). In this first representational strategy, the constitutive spectre of the stereotyped, limp-wristed, effeminate fairy was contained by maintaining and foregrounding the heteromasculine attributes of conventional athletic masculinity. These corporeal athletic reminders kept invisible and silent the trope of the fag, containing the homosexual threat for public media consumption. Toby Miller (1998) has suggested that by the mid-1990s, it was possible to be a successful gay male sporting hero if representational strategies publicly assimilated and kept intact the configurations of dominant, conventional heteromasculinity. Miller's analysis uses Ian Roberts as exemplar. Roberts, a popular Australian rugby player, had, for the most part, successfully managed coming out as gay and maintained his popular appeal in the late-90s through foregrounding a very typically athletically strong, hegemonic masculinity. In the mid-1980s, the Bay Area press predated Miller's claim. "Thomas Flubacher Waddell, M.D., died at his home in San Francisco Saturday morning. In the 1968 Olympics in Mexico City, Dr. Waddell placed sixth in the decathlon. By traditional standards, that made him the sixth greatest athlete in the world" (Moor 41). This is one among many media invocations of Waddell's strength and athleticism (Tom Waddell Dead B1, Scheer 33, Mandel B3, Fernandez B1). In death, Waddell, through the same kinds of representational logic, was made palatable to a mainstream San Francisco public in the late-1980s.

${ }^{3}$ The Bay Area Reporter (BAR), no longer in existence, was to date the longest running gay and lesbian newspaper in the San Francisco Bay Area. 
In addition to the invocations of sporting prowess, Waddell's wife and child were positioned as the bereaved family. Repeated reliance on the pervasive heteronormative construction of family exceeded the minor inconveniences of the lesbian mom and gay dad who did not cohabitate, giving texture to the second representational strategy of Waddell. Before his death, Waddell actively colluded in the discourses of husband, father, and normative family. He often invoked three-year old Jessica as the guiding light in his life and said his one regret in death would be not to witness her growing up (Fernandez; Scheer; "Tom Waddell dead"). Sara Lewinstein became the bereaved widow, Waddell's best friend and support: simply "We loved each other" (Lewinstein in "Tom Waddell dead" B1). With one exception (White 1987b), Zohn Artman, Waddell's last male lover, sometime housemate, and long time confidante-the queer excess-was made invisible in the public bereavement process. Artman and Waddell were both diagnosed with AIDS within a short time of each other and spent their final months nursing one another through the disease (Waddell \& Schaap). Artman died in October of 1987, a few months after Waddell (Newquist).

\section{Attempting to Mourn}

In the months and years following the Supreme Court's Gay Olympics decision and Waddell's death, the Gay Games' community symbolized Waddell and his memory, attempting to bring closure, to mourn, ${ }^{4}$ that crucial loss. In the immediate wake of his death, the invocation of Waddell was used strategically at various times, often

${ }^{4}$ According to one of Freud's early ideas about grief and loss, when one loses an object (such as a beloved person) or an ideal, the experience of loss is either mourned or not. When one mourns a lost object or ideal, s/he severs their psychic attachment to it, $s /$ he acknowledges the loss, and $s / h e$ comes to symbolise the lost object and move their libidinal attachments onto new objects or ideals. They are able to let the person / object / ideal go whilst still "remembering" (Butler 1990; 1997; Gay). In his text "Mourning and Melancholia," Freud made a distinction between mourning and melancholia. Mourning is a grief process in which to properly resolve a loss, there must be a breaking of the attachment to that object (Gay). "Separation is recognized and the libido attached to the original object is successfully displaced onto a new substitute object"' (Butler 1990, 84). This process is called introjection, and, if it is to be successful, "the capacity to symbolize experience needs to be developed as a way of coping with separation and loss. For it is only via the representation of the object in its absence that the symbol can come to replace the loss as a memory" (Diamond 177). 
to indict the USOC and Olympic movement, especially in the Visa and Bay Area Olympic Bid protests. His memory has been used contradictorily to support projects that some believe would have appalled him. In 1988, Mary Dunlap (the Gay Games' pro-bono attorney) and Sara Lewinstein accused each other of gratuitously misrepresenting Waddell's principles concerning whether or not he would have supported an Olympic bid for San Francisco (Dunlap; Mandel 1988; SFAA Board 1988). Almost every bid proposal prepared to host a Gay Games has gone to great lengths to discuss how they would honour Waddell's memory by fulfilling his philosophies on sport, sexuality and/or participation. ${ }^{5}$

Tom Waddell has been immortalised through the Gay Games movement. Made static, aspects of him hauntingly function to inform the directives of the FGG. Fixing him in a collective memory happened almost immediately upon his death. Male Entertainment Network (MEN video), the official "filmmaker" of the first two Gay Games, made a video of Waddell's public memorial tribute held in the rotunda of the San Francisco City Hall in 1987. It was sold as a "public service" for ten dollars, theoretically the cost of production (White 1987b). San Francisco Chronicle columnist Bill Mandel lamented eight months after Waddell's death that he was losing the "real 3-D Tom" who was emerging as a martyr less than a year after his death (Mandel 1988, A5). In 1988, Waddell's memory was preserved through seven panels on the AIDS Memorial Quilt, more than any other individual at that time (Waddell \& Schaap); and, in 1990, a Celebration ' 90 newsletter headline proclaimed, "Waddell's dream of international Gay Games fulfilled" (McDell 4).

Further reiterations of the good Tom Waddell continued unabated. In the lead up to the New York Games in 1994, nostalgic remembrances of the founder Waddell were printed in the Gay Games IV newsletter, Unity' 94 (Schaap 1991). Lewinstein spearheaded the development of Tom Waddell commemorative coins (echoing the Olympic collector coins), which would be sold as a fundraising

${ }^{5}$ An example of this comes from the closing sentence of the cover letter that introduced New York's successful 1994 bid. "If Dr. Tom Waddell (who spent so much of his time in New York City) had survived the AIDS epidemic, he would be proud to celebrate the $25^{\text {th }}$ Anniversary of Stonewall and Games IV in 1994 with his global sisters and brothers, gay and straight. In 1994 we will have his spirit here in New York City" (Board of Directors 2). 
venture for the FGG. The coins featured an image of Tom Waddell's head on one side and the FGG logo on the other. The FGG received $5 \%$ of all revenue generated from their sale (Peterson \& Kennedy). The Gay Games and Tom Waddell were two sides of the same coin, literally embossed together in enduring memory.

During the 1994 Opening Ceremonies of Gay Games IV in New York City, a Tom Waddell video tribute was played over the huge screen in Wien Stadium at Columbia University to the 25,000 strong Opening Ceremonies crowd. The video was introduced by American Olympic medallist, swimmer Bruce Hayes, and was followed by eleven-year old Jessica Waddell Lewinstein who read a poem she had written about her dead father ("Opening Ceremonies"; Waddell \& Schaap). The choreography of the ceremonies was carefully orchestrated to create the imaginary Olympic gay pride moment. As the Gay Games IV Games Guide described it, "Truly Olympian in scope, Opening Ceremonies are designed to evoke feelings similar to those experienced by Dr. Tom Waddell as he entered the stadium in Mexico City in 1968, where the idea for the Gay Games was born" ("Opening \& Closing" 44). The never-ending quest for origins was solidified through the opening and closing spectacles of the fourth Gay Games: Waddell was invoked in the beginning and at the end (respectively at the Opening and Closing Ceremonies), when his wife and child presented the Waddell Cup for the second time ("Closing Ceremonies").

Indeed, one of the most enduring and public symbolizations of Waddell's memory is the Waddell Cup, awarded at each Gay Games. Given for the first time in 1990, the trophy honour is awarded to recognise the most deserving volunteer participant at each Gay Games. This trophy has become an interesting metaphor for the rationalisation and image-making of the FGG organisation while simultaneously reiterating a certain memory of Waddell. Rob Neyts purchased and donated the trophy after fundraising in the Vancouver leather community. By default, the responsibility for the Cup fell to the newly formed FGG and an Awards Committee was struck to govern the Waddell Cup and its bylaws (FGG Executive 1989; FGG Executive 1991; Neyts). After a hurried call for nominees, the Tom Waddell Memorial Cup was presented for the first time at Gay Games III to long time Gay Games organiser and volunteer Paul Mart. Lewinstein presented the trophy at the Closing Ceremonies with her 
and Waddell's then 6-year old daughter (FGG Executive 1990; Forzley \& Hughes).

The history of the Tom Waddell Memorial Cup represents the memory of Waddell and his legacy in several interesting and contradictory ways. The trophy's creation through the grassroots initiative of Neyts and the financial support of the Vancouver leather community harkens back to the very first Gay Games where spontaneous gay community support was embraced and encouraged. In Waddell's weekly BAR columns in 1981 and 1982, he revelled in and marvelled about the subcultural elements of the gay community that championed the Gay Olympics. Among others, supporters were the Sisters of Perpetual Indulgence, the very uncloistered group of nuns in drag who performed half time shows at basketball games, and the locally famous and popular gay male sex show, Men Behind Bars (Waddell).

In the mid-1980s, due in part to the AIDS epidemic taking its massive toll on gay men's lives and the resulting clamp down on unbridled homosexual activity, the Gay Games rhetoric, led in large measure by Waddell, shifted to downplay and almost erase sex, particularly any explicit homosexually-inflected sex or representations thereof. The Gay Games were to be about meeting human potential and were not to be defined by (homo)sexuality. This sexless discourse has become, ironically, the unofficial official discourse of the Gay Games (Probyn). Waddell gave interviews to the straight press, in which he insisted that the explicitness of sex in the gay ghetto was not the norm, but was practised by a minority and fetishised by the media (Fernandez; Moor; Scheer). At an SFAA ${ }^{6}$ board meeting in March 1986, Waddell was adamant that while "safesex" information could be made available during Gay Games II, condoms would absolutely not be distributed, as this would give the "wrong" impression and detract from the spirit and purpose of the event (SFAA Board 1986). The effect was to desexualise and sanitise gays and lesbians so they could more easily assimilate and take their place at the heteronormative athletic table.

\footnotetext{
${ }^{6}$ San Francisco Arts \& Athletics, Inc. (SFAA) was the organization responsible for putting on Gay Games I and II in San Francisco. It was disbanded in 1989 to form the Federation of Gay Games (FGG), the international body for the Gay Games movement.
} 
In the official FGG information about the Waddell Cup there was absolutely no mention that its financial condition of possibility was predominantly the gay male leather community of Vancouver. Instead, isolated individuals who had donated significantly for the trophy were thanked in the Celebration '90 Official Program ("Tom Waddell" 1990), and the cup was described as a gift to the Gay Games from Vancouver, headed up by Rob Neyts, who professed to be so moved by Tom Waddell's life story that he wanted to create an award for an exceptional participant ("Personal Trophy"). The official call for nominations read, "the award is intended to honour an outstanding Gay Games individual.... exemplifying the spirit and pride of Gay Games Founder Tom Waddell" (Farrell 1). It was as if there had to be a necessary distancing of the hero Waddell from the taint of a transgressive gay sexual reality. In fact, there was correspondence to the MVAAA $^{7}$ from groups inquiring whether a leather presence and/ or participation would even be welcome at Gay Games III ("Letter"; MVAAA Board). For some groups, the presumption of inclusivity, no matter how explicit, could not be assumed.

Waddell's philosophy of "inclusion and participation for all" is bizarrely twisted in how he is remembered and immortalised through the Waddell Cup. One of the criteria for the Waddell Cup is "someone who personifies the standards of selflessness, devotion, humility, dignity and love of humanity set by the late Dr. Tom Waddell" (Farrell 2). By foregrounding these idealized attributes, the Gay Games keep intact a version of Tom Waddell that seamlessly integrates athleticism and gay pride with the "true" goodness of humanity, one which does not engage any explicit sexuality. The Waddell Cup winner symbolises for a short time at each Gay Games the lost Tom Waddell-a hopeful but ultimately ineffective replacement, a mournful substitute to be revived every four years.

Another powerfully evocative tactic to keep Tom Waddell "alive" has been how his daughter, Jessica, has been deployed throughout Gay Games discourse. A picture of Waddell holding 3-year-old blonde Jessica at Gay Games II is one of the most enduring pictures of the Games' founder. She has been a presence at every Gay Games since her father died in 1987. A bored seven-year old on the Closing Cer-

${ }^{7}$ MVAAA is Metropolitan Vancouver Arts and Athletics Association. This group was formed to organize Gay Games III “Celebration" in Vancouver, BC in 1990. 
emonies stage in 1990 at the Vancouver Gay Games (Forzley \& Hughes), her profile at the New York Games was much higher. There, as noted, the eleven-year-old read her own poetry about her father to 25,000 people and presented trophies ("Closing Ceremonies"; "Opening Ceremonies"; Waddell \& Schaap). For Gay Games IV, Sara and Jessica hosted the media reception that launched the Rainbow Run for the End of AIDS at Waddell's Albion Street home in the Mission District in San Francisco (American Run). The mother and daughter duo also had a large photographic presence at Gay Games V in Amsterdam ("Photo file"). Daughter Jessica is the closest live emulation of the lost hero. Since his death, Jessica and Sara have been used discursively to subtly keep in place a heteronormative myth, a safe, conventional familial structure. Wittingly or not, the Gay Games have used this conservative symbolism.

The Gay Games have also capitalised on gay Olympic heroes, heroes who were necessarily public Olympians before they were publicly gay. Tom Waddell is remembered as implicitly creating this dynamic: "Tom represented the spirit of the Olympics. He was a true Olympian" (Brazil B8). Olympic swimming gold medallist Bruce Hayes came out to the sporting world in Vancouver in 1990 and was a major poster boy in the promotional campaign for Gay Games IV (New York in '94; Weiss). US gold medal diver Greg Louganis came out at the 1994 Games in New York. His videotaped words, "It's great to be out and proud" drew thunderous applause at the Opening Ceremonies in New York (Louganis in Waddell \& Schaap 233).

Three weeks later, Louganis received an award for fairness, commitment to excellence, and dedication to sport and athletics from the USOC. When he accepted the honour, Louganis dedicated it to the late Dr. Tom Waddell, characterising Waddell to the pro-Olympic crowd as founder of the Gay Games, US Olympic athlete, and victim of AIDS. The reception from the American Olympic pundits was less than enthusiastic. Many of the USOC officials in that crowd "had been shocked and offended by Tom Waddell's desire to call his festival the Gay Olympics. Some of those officials had been part of the campaign to strip the word 'Olympics' from the title of the Gay Games, part of the campaign to harass and sue Tom Waddell" (Louganis in Waddell \& Schaap ix). Waddell not only haunted the Gay Games then, but also continued to be invoked within the circles of American Olympic power. It was at this US Olympic Festival in St. 


\section{$128 /$ J. Davidson}

Louis that Louganis also called on the USOC to remove any Olympic events or activities from Cobb County, Georgia where homophobic, anti-sodomy laws had recently been revived and supported. After reading Waddell's story in The Gay Olympian, Louganis suggested that he felt like he knew Waddell, sharing an affinity with being a gay man in elite athletics. He thought Waddell would have approved of his call to boycott Cobb County (Waddell \& Schaap xi).

The Gay Games founder has thus been thoroughly symbolised to represent a certain vision for the event. The attempts to symbolically remember Tom Waddell-through the trophy, the coins, his daughter, the unrelenting invocation of his philosophies and ideals-are endeavours to mourn the man and let him go. These efforts to mourn Waddell, however, to let him go through symbolization, have necessarily failed. This complicated grieving cannot just be understood through a mourning process that allows for Waddell's death. It cannot bring closure for the Gay Games, as the mourning can only be operationalised as an effect of a previous melancholic identification.

While the attempts to remember him symbolically may point toward a letting go, they also function to keep Waddell "alive" psychically and the unspoken denial of his loss is represented through the public, social manifestations of homage to the "great man." The Gay Games have been unable to give up both the ideal of the (homophobic) Olympics and the object of Tom Waddell. The strategic and poignant use of Waddell's daughter gives good evidence to the very problematic facing the Gay Games. The next closest thing to the actual lost object of Waddell is his own flesh and blood, the biological, genetic progeny that comes to represent him, but of course is not him. A naturalised, teleological discourse of the human condition is subtly reinscribed through this incorporative process. It is to some of the processes of incorporation and melancholia that I now turn.

\section{A Melancholic Haunting: The ego ideal and ideal $\mathrm{ego}^{8}$}

As I briefly outlined in my introductory comments, the second part of this paper asks about the effects for the Gay Games of "hanging onto" Tom Waddell through particular memorial practices. As I have

${ }^{8}$ I acknowledge from the outset of this argument that attempting to psychoanalytically understand and analyze culture and organizations is a fraught 
argued, the figure of Tom Waddell watches over the Gay Games-a never-ending and contradictory haunting. What dynamics are operating to sustain this memory? How do the Gay Games hold onto Tom Waddell, never letting go of their lost object? One way of reading Waddell's haunting is to consider, in a Lacanian sense, how the figure of Tom Waddell functions to mediate between the ego ideal and ideal ego of the Gay Games organisation. I turn first to outlining this conceptualization of the ego ideal and ideal ego, followed by its consideration in the context of this paper.

Within a Lacanian psychoanalytic framework, the two concepts of ego ideal and ideal ego relate, respectively, to two of the Lacanian orders, the symbolic and the imaginary. The symbolic is primarily a linguistic dimension in which cultural and social realms are produced through the functioning of language. The subject is a symbolic construction. The imaginary order is a specular realm, dominated by the image, typically an ideal image from which all humans are inescapably alienated. "Lacan places a special emphasis on the role of the image, defining identification as the 'transformation that takes place in the subject when he assumes an image.' To 'assume' an image is to recognise oneself in the image, and to appropriate the image as oneself" (Evans 81). This is the basis of the fable of the mirror stage, that dynamic by which the ego is constituted, and which "represents a permanent structure of subjectivity, the paradigm of the imaginary order" (Evans 115; Leader \& Groves; Zizek).

The production of the ego and subject happens early. The human infant is radically dependent and not a pre-given totality. To survive, it must attach to a primary caregiver (in the patriarchal culture of

enterprise. In the larger dissertation project (Davidson), I make a sustained argument for the Gay Games' organization to be accorded an "ego," in order to make sense of how the Gay Games has melancholically incorporated the loss of the homophobic Olympics to produce a very prideful gay athletic event. I recognize this is not a straightforward move, nor one that will be accepted in all quarters. While Judith Butler (1997) refers to the psychic incorporation of individual subjects, she also suggests that "when certain kinds of losses are compelled by a set of culturally prevalent prohibitions, we might expect a culturally prevalent form of melancholia, one which signals the internalization of the ungrieved and ungrievable homosexual cathexis. And where there is no public recognition or discourse through which such a loss might be named and mourned, then melancholia takes on cultural dimensions of contemporary consequence" (139). Butler continues this conversation in her recent book Precarious Life: The Powers of Mourning and Violence (2004). 


\section{0 / J. Davidson}

Freud and Lacan, this is predictably the mother figure). As the infant matures and starts to differentiate, psychoanalysis suggests certain dynamics occur in which the ego and, ultimately, the subject are produced. During the mirror stage, the child sees in its reflection a complete wholeness-plenitude. That image may be reflected in an actual mirror or the baby may see itself reflected in the primary caregiver or another child. This méconnaissance is not to be read as a literal act necessarily, but understood as a trope for necessary misrecognitions that will occur continuously throughout a subject's life.

The child recognises in this inversion a reflection of the perfect union of caregiver and child, and then realises a fundamental split between the reflection and itself. It misrecognises itself in the mirrored image (understood as wholeness, unity, totality-the perfect fulfilment of desire), cognisant of a disjuncture between its reality and the reflection. The reflected image of bond between child and caregiver is idealised in the imaginary as that ideal, blissful state where the child's every need, want, and desire is fulfilled completely with the caregiver. The domain of the desired image is the imaginary order, the psychic realm where the ego is produced over and over again through identifications with desired objects and ideals (Aoki 1999a; 1999b; Evans; Leader \& Groves; Zizek).

It is from a position of otherness that the child recognises itself in the split between its inadequacy and the reflection of perfection. "The child identifies with an image outside him[/her]self" (Leader \& Groves 21). The ego is the result of identifying with the image of itself as whole. The dissonance between the two (wholeness and the uncoordinated "baby" body) is alienating, as the child desires to perceive itself as the counterpart. The child realises that the body it has in relation to the idealised image of the Imaginary mirror phase is an incomplete body, which is experienced as a fragmented body. For the infant, the contrast is felt as a threat, which "gives rise to an aggressive tension between the subject and the image" (Evans 115). The subject is split from itself, and the desire to fulfil the unity of the caregiver / child union propels the child into language. In attempting to signify its desire for the fulfilment of plenitude (the mirrored image), the child is subjected to the Law, becoming a subject within the symbolic order (Evans; Leader \& Groves; Zizek).

The mirror phase is the primary identification producing the ego in the imaginary order. A secondary identification must occur for 
"the passage from the imaginary order to the symbolic order," and this secondary identification concludes the Oedipus complex (Evans 127). In the contentious Oedipal complex, it is suggested that the child realises that s/he cannot fulfil the primary caregiver's (typically the mother's) imagined desire beyond the child itself (represented by the phallus ${ }^{9}$ ), because the Name of the Father (the symbolic law, language, the nom/non du père) has the phallus, and is neither sharing nor exchanging it. This prohibition relieves the child of the responsibility of trying to be the phallus to fulfil the mother's desire, and instead, the child identifies (through a forced prohibition in the so-called "castration complex") with the Name of the Father (entry into language, the symbolic order, subjecthood). "The phallus represents what we lose in entering the world of language-the fact that the message will always be slipping away, that what we want will always be out of reach because of the fact that we speak" (Leader \& Groves 99). Lack (of unity or wholeness) propels the subject into language to attempt to attain that original desire for the ideal. The subject continues to misrecognise its ideal, and now attempts to fulfil that lack through language in the symbolic order. Language, in its constant deferral of meaning, cannot fulfil the desire. The reflected unity of wholeness is an unattainable ideal, which is paradoxically ordered and stabilised from within the symbolic order (Evans; Leader \& Groves). The ideal ego and ego ideal each emerge out of the production of the ego (an imaginary identification) and the subject (a symbolic identification). "The mirror stage constitutes the "primary identification' and gives birth to the ideal ego" (Evans 81). The ideal

${ }^{9}$ Phallus is a difficult and disputatious term. I have resisted agreeing to its use for a long time. Suffice to say that, in a Lacanian sense, the phallus is not the penis. In the imaginary, it is the object that the mother desires beyond the child, and which the child, in the preoedipal phase, attempts to "be," however it is always out of the child's reach. "The child is trying to be the object which it thinks the mother lacks. The phallus is just the name for this object: that which the mother lacks" (Leader \& Groves 103). In the symbolic, the phallus becomes the ultimate signifier that has no specular image. It is this phallus that is "castrated" from the child, differentiating him/her from the mother and propelling the child into symbolic subjecthood, beyond the imaginary realm of mother and child. The phallus "is described as the 'signifier of the desire of the Other,' and the signifier of jouissance" (Evans 142). Certain feminists have denounced Lacan's use of phallus as reinscribing patriarchal privilege. Derrida has critiqued the notion of a transcendental signifier as simply another form of the metaphysics of presence, repeating a system of thought that is phallogocentric (Evans; Leader \& Groves). 
ego is the spectacle offered to the gaze. It is the image that is to be seen, the image you want to have of yourself.

\section{Imaginary Identification: Waddell as Ideal Ego}

For the Gay Games, the primary identification is with an ineluctable ideal of a Gay Olympics. The Gay Games' ideal ego is a utopic vision of a celebration of out and proud homosexual athleticism that is accorded the same status and grandeur as the International Olympics. In 1982, however, the organisation had an experience of alienation and fragmentation when it had to encounter what it actually was-a tiny, grassroots organisation being mercilessly hounded by the homophobic USOC, with Tom Waddell as a particular target in that harassment.

The figure of Waddell represents in many interesting ways the ideal ego for the Gay Games. Waddell embodied the image of the gay Olympian at the 1968 Mexico City Summer Olympics-a romanticised image the Gay Games needed for its primary identification. Waddell was an extremely charismatic, likeable and articulate man. He was able to transmit his ideal of a Gay Olympics full of other Gay Olympians in Technicolor for others, particularly other lesbian and gay athletes. He loved being an Olympic athlete. In imaginary identification (the ideal ego), identification occurs "with the image in which we appear likeable to ourselves, with the image representing "what we would like to be"" (Zizek 105). The image of "what the Gay Games would like to be" is identified with Waddell's love for the Olympic movement, his success as an Olympic athlete, and after his death, the connection of successful (gay) Olympic athletes to the Gay Games, all of whom constantly paid homage to the path blazed by Tom Waddell. The Gay Games really wanted (and wants) to be (to identify with) a utopic Gay Olympics.

While Waddell has been cast as the symbol of a Gay Olympian, the fact was, at the time of the 1968 Summer Olympics, Waddell was a very closeted fag. In the formation of the ideal ego, "the feature, the trait on the basis of which we identify with someone, is usually hidden-it is by no means necessarily a glamorous feature" (Zizek 105 ). While the image of a very out and proud Gay Olympics seems to make up the ideal ego, it is the illusion of pride that is necessarily propped up by homophobic, queer shame. Zizek suggests that weakness or guilt can act as identifying traits. I would add shame to 
that list of possibilities, as it is the necessity of a shaming athletic and sporting establishment that even makes possible the need for the dream of an ideal Gay Olympics.

"Imaginary identification is always identification on behalf of a certain gaze in the Other. The question to ask is: 'For whom is the subject enacting this role? Which gaze is considered when the subject identifies himself with a certain image'?" (Zizek 106, emphasis in the original). In the case of the Gay Games and their ideal ego of a Gay Olympics, the gaze they are trying to attract, the gaze that they are considering, is the gaze of approval from the conventional, international Olympics. The early Gay Games spent much promotional energy representing the events as serious amateur athletic competition. Sanctioning each athletic event, using certified officials, and promoting serious elite athletes who agreed to participate (particularly through endorsements and/or participation by former Olympians), indicated that the Gay Games were able to attract serious competition and were athletic events of note. The downplaying of sexuality throughout the Games (best represented in the discourse of "we are more than just our (homo)sexuality") may in part be motivated through an attempt to consider the gaze of the international Olympic community. The discursive position produced is one of "even though we're gay, we're still worth endorsing because we represent serious amateur athleticism."

Waddell's figure plays an interesting role here as well. In the late 1960s he was on contract with the USOC as a medical advisora role that indicated some level of approval by the governing body. Depending on which archival narrative is privileged, one of the stories about the very early organising stages of Gay Games I is that Waddell initiated contact and wrote the USOC to request their approval of his use of the word "Olympic" (Davidson 51). Interestingly, a Gay Olympics primary identification was maintained (maintaining the shame / pride binary construction) even after the USOC request was denied. Those who were able to use the word "Olympic" (local politicians, authors of letters to the editor, etc.) after the court injunction were encouraged to do so (Davidson 57-58). Waddell fervently believed in and wanted "true" Olympism to be part of his event and he wanted that similarity recognised publicly in the Gay Olympics. His identification with the Olympics is poignantly reflected in a statement he made weeks before his death, 
just after the Supreme Court made its ruling. "Why are gay people the only people in the world who can't use [the word 'Olympic']?" (Repa 20). This followed tough talk from a year earlier, when Waddell vowed that even if they could use the word, they wouldn't (Coe). In 1993, a little over ten years after the first Games, the Federation of Gay Games was hosted by the USOC at the USOC's invitation, a shift that was hailed as a major breakthrough in the "maturity" of the Gay Games.

Another way to understand "identifying on behalf of a certain gaze in the Other" is to consider what the gaze does in terms of producing the ideal ego. The Gay Games identified with the Olympics through an idealised Gay Olympics, and have fashioned themselves accordingly to try to gain Olympic approval ever since. The gaze of the Other was not, say, the gaze of a grassroots sports organisation. If the Gay Games had identified with an alternative sporting movement, their ideal ego would have been produced very differently. Gay Games' attorney Mary Dunlap's crusade for freeing up the term "Olympic," to be used for a whole variety of amateur sporting and recreation activities and events, illustrated that there was no identification with that cause. The dream of an emancipated Olympics was Dunlap's alone, and she could carry the cause only so far (Davidson 93).

\section{Symbolic Identification - Waddell as Ego Ideal}

The image of a Gay Olympics is only an imaginary moment. As soon as that primary identification is brought into the symbolic order through a secondary identification (which is necessary to become a subject), it necessarily fails because language in the symbolic cannot fully express meaning. The "ideal ego is always subordinated to ego ideal: it is the symbolic identification (the point from which we are observed) which dominates and determines the image" (Zizek 108). In symbolic identification, "identification of the subject with some signifying feature [or] trait, in the big Other, in the symbolic order occurs ... [The ego ideal] assumes concrete, recognizable shape in a name or in a mandate that the subject takes upon himself and/or is bestowed on him" (Zizek 104).

The ego ideal was bestowed upon the Gay Games through the prohibition of a Gay Olympics. Indeed, the Gay Games were brought into language (and being) by the prohibition on the word "Olympic." 
The law (the literal judicial law of the Supreme Court that represents the Law of the Father-the symbolic law) forced the Gay Games to define themselves according to a network of disciplining symbols outside of an imaginary dyad of Gay (and) Olympics. To become a viable "cultural subject," the Gay Games were forced to subjectivate themselves to the symbolic (Leader \& Groves). The law does not forbid the Gay Games, only the Gay Olympics. The ego ideal (symbolic identification) was then produced through identification with what remains and that was gay pride (in a myriad of manifestations) at the Gay Games. The law facilitates the production of the event:

The constitution of the ego by identification with something which is outside (and even against) the subject is what "structures the subject as a rival with himself" and thus involves aggressivity and alienation ... Symbolic identification is the identification with the father [being named, brought into language] in the final stage of the Oedipus Complex which gives rise to the formation of the ego-ideal. It is by means of this secondary identification that the subject transcends the aggressivity inherent in the primary identification. (Evans 81 )

The primary identification with a Gay Olympics was in contradistinction to the gay pride of the Gay Games. As they tried to emulate the international Olympics, the small, shoestring organisation felt alienated. The newly formed subject of the Gay Games transcended the foreclosed Gay Olympics identification. The Gay Games produced an ever more successful event, almost approximating (but never quite completely) Olympic splendour. The secondary (symbolic) identification with gay pride effectively transcends the alienation felt in the original identification by a fledgling queer organisation identifying with an Olympic edifice. The celebration of the Gay Games is predicated upon gay pride, but the event disavows carefully and fastidiously any formal Olympic connection. A Gay Olympics is foreclosed, meaning it cannot return in the symbolic, and thus Gay Games pride is about the Gay Games and not about the Olympics. "Since the symbolic is the realm of the law, and since the Oedipus complex is the conquest of the symbolic order, it has a normative and normalising function" (Evans 129). The prohibition on Olympic clearly illustrates how the Name of the Father 
prohibits the subject from having the phallus, which, in this case, is the dream of a Gay Olympics. That symbolic prohibition also cements homophobic shame to a Gay Olympics.

The ego ideal, as symbolic identification, is "identification with the very place from where we are being observed, from where we look at ourselves so that we appear to ourselves likeable, worthy of love" (Zizek 105). The Gay Games must observe themselves from a place of gay pride so that the Gay Games can recuperate and celebrate queer athleticism in the symbolic order. The ego ideal is gay pride that matches and even rivals the intensity of Olympic pride, glamour and discipline. The ego ideal is sustained through the specular images of athletic pride that are put on vibrant display at every Gay Games spectacle.

Tom Waddell, as the founder and main organiser of the inaugural Gay Games, celebrated gay pride at every point in the first event. As Heather-Zwicker (2002) has noted, pride is, among other things, about not backing down, and Waddell absolutely did not retreat from repeated and serious threats from the USOC. The ego ideal of Gay Games pride was situated in Tom Waddell's vision of gay pride. And, when the living version of Waddell was no longer present, the measure of gay pride has often been accounted for in appeals to Waddell's memory and vision for the Gay Games. Almost every major decision and policy direction the FGG has taken has been justified through invoking Waddell's philosophy as it aligns with his vision of gay pride through organised athleticism.

Waddell functions as a psychic "good bargain" for the Gay Games as he is a "two-fer"-a two-for-one deal. He appears to inhabit both the ideal ego and the ego ideal. To sustain identification, the necessary illusion is that the ideal ego and the ego ideal cohere, but it is an illusion-an identification that is based on misrecognition. While Waddell's figure seems to embody both the ideal ego and ego ideal simultaneously, there is a constant slipping back and forth of a metonymic dance between a Gay Games pride and a Gay Olympics dream propped up by a shaming Olympics. The ego ideal is the position from which you can be misrecognised as your ideal ego. It would only be from a position of Gay Games gay pride (the ego ideal) that the Gay Games would (mis)recognise themselves as the utopic Gay Olympics, and each of the ego ideal and ideal ego could use the figure of Tom Waddell to support either purpose. 
In imaginary identification, we "imitate the other at the level of resemblance ... We identify ourselves with the image of the other inasmuch as we are "like him"' (Zizek 109). The other the Gay Games desires to imitate - to be "like them"-is the International Olympic Games. Over against imaginary identification, however, is symbolic identification in which we "identify ourselves with the other precisely at a point at which he is inimitable, at the point which eludes resemblance" (Zizek 109). The Gay Games enter the symbolic realm right at the point that the Olympics are prohibited for them. They are too queer, too threatening and must be made abject. The Olympics must become inimitable for the Gay Games. For, at the point that an imaginary identification is fulfilled within the symbolic, psychosis occurs (Leader \& Groves). But the ego ideal identification with gay pride supplants the Olympic dream to produce a proud Gay Games identification. "This interplay of imaginary and symbolic identification under the domination of symbolic identification constitutes the mechanism by means of which the subject is integrated into a given socio-symbolic field-the way he/she assumes certain mandates" (Zizek 110). The inescapable symbolic identification with gay pride for the Gay Games plays itself out in the production of the very "prideful" gay and lesbian athletic spectacle.

The formation of the ego ideal is the culmination of the Oedipal identification with the Father (Butler 1990; Evans). The ego ideal is related to the judging superego: "The superego is an unconscious agency whose function is to repress sexual desire for the mother, whereas the ego-ideal exerts a conscious pressure towards sublimation and provides the coordinates which enable the subject to take up a sexual position as a man or a woman" (Evans 52). The figure of the mother in the Oedipal complex functions as shaming Olympism in the production of the Gay Games. The Gay Games' superego represses the shame (of the shaming Olympics) that is an integral part of the constitutive moment for the event. Olympism must also be repressed. The ego ideal, as gay pride at the Gay Games, identifies with the "gay" half of the prohibited Gay Olympics. The father figure for the Gay Games is gay pride. Gay pride (standing in for the father) must be identified with, while the sacred Olympics, representing the phallus the Gay Games cannot have, is let go by the male child. In the production of a male subject, the Law of the Father holds out the promise that someday the male child will get 
the phallus back - will have the phallus - but that, implicitly, it must be given up now (Leader \& Groves). The Gay Games shall continue to seek the promise of the fulfilment of the Olympic phallus, continue to function as a place of male privilege and patriarchal power, and have, over the years, attempted to court the approval of the USOC (Davidson 138-142).

Waddell's loss therefore works in complicated ways and functions, contradictorily at times, to support and mediate between the ideal ego and ego ideal, subtly guiding the formation and trajectory of Gay Games discourse. The Gay Games subject is the out, proud, gay athlete and Waddell's image insistently governs its representations. He is lurking in the ideal ego of a utopic Gay Olympics that he almost embodied and attempted to create. As ego ideal, Waddell decidedly urges gay athletic pride on, being in his life and his death one of the Gay Games' loudest pride cheerleaders. However, what the memorial practices of the Gay Games do in insistently remembering and paying homage to Tom Waddell is to keep intact the loss of the dream of a Gay Olympics. While ostensibly celebrating the gay athletic pride philosophy that he so fiercely championed, Waddell's figure concomitantly reinscribes the homophobic blow the USOC and US Supreme Court delivered in 1987 when they foreclosed the Gay Olympics. The Gay Games emerged, metonymically linked with Waddell, to be founded and predicated on that injurious loss - a shameful loss that is unwittingly remembered and necessarily reiterated in complicated ways through Gay Games memorial practices.

\section{Works Cited}

The following frequently cited abbreviations are used:

BAR - Bay Area Reporter, San Francisco.

FGG - Federation of Gay Games

GG - Gay Games

GLC - Gay and Lesbian Center Collection in the SFPL History Centre.

MVAAA - Metropolitan Vancouver Athletic and Arts Association SFAA - San Francisco Arts and Athletics, Inc.

SFPL - San Francisco Public Library 
Aoki, Doug. Lecture notes. Sociology 537 - Sociology of Knowledge, Department of Sociology, Faculty of Arts, University of Alberta, Edmonton, Alberta, Canada. January-April, 1999a.

Aoki, Doug. Lecture notes. Sociology 631 - Seminar in Advanced Sociological Theory: Judith Butler and Slavoj Zizek, Department of Sociology, Faculty of Arts, University of Alberta, Edmonton, Alberta, Canada. September-December, 1999b.

The American Run for the End of AIDS. "International Rainbow Memorial Run." Information sheet. SFPL, GLC 27, Box - FGG Business 95-96, 1998.

Board of Directors - New York in '94. [Bid Proposal]. SFPL, GLC 27, Box - Derek GG IV NYC 1994, File - Big Blue Binder. 30 March, 1990.

Brazil, Eric. "Tom Waddell: Tribute to a 'true Olympian'." San Francisco Chronicle 19 July 1987: B1, B8.

Butler, Judith. Gender Trouble: Feminism and the Subversion of Identity. New York: Routledge, 1990.

-The Psychic Life of Power: Theories in Subjection. Stanford, CA: Stanford University Press, 1997.

Closing Ceremonies - Gay Games IV. Official Program. SFPL, GLC 27, Box - Derek GG IV NYC 1994. 25 June, 1994.

Coe, Roy M. A Sense of Pride: The Story of Gay Games II. San Francisco: Pride Publications, 1986.

Conkin, D. "Longtime community leader Rikki Streicher dies." $B A R$ 25 August 1994: 1,6.

Davidson, J. "The wannabe Olympics: The Gay Games, Olympism, and processes of incorporation." Diss. U of Alberta, 2003.

Diamond, Nicola. "Introjection." Feminism and Psychoanalysis: A Critical Dictionary. Ed. Elizabeth Wright. Oxford: Blackwell, 1992. 176-178.

Dunlap, Mary. Letter to Sara Lewinstein. SFPL, GLC 27, Box \#3 Games Clippings, File - Minutes from SFAA Board - GG II, \#2. 31 March 1988.

Evans, Dylan. An Introductory Dictionary of Lacanian Psychoanalysis. London:Routledge, 1996.

Farrell, Dee. "FGG seeks nominees for the Waddell Cup." Press release. SFPL, GLC 27, Box - FGG Business 82-94, File: Dereks' Red Binder - FGG 1989 thru 1994. 10 June 1990. 
Fernandez, Elizabeth. (1987, March 15). “AIDS: Olympian's most demanding test." San Francisco Chronicle 15 March 1987: B1. FGG Board of Directors. Meeting minutes. SFPL, GLC 27, Box FGG Business 82-94, File: Federation Board Meeting Information and Minutes October 91-November 92. 2 June 1990.

FGG Executive Committee. Conference Call minutes. SFPL, GLC 27, Box - FGG Business 82-94, File: Federation Executive Minutes 1987-88. 10 October 1989.

- Conference Call minutes. SFPL, GLC 27, Box - FGG Business 82-94, File: Federation Board Meeting Information and Minutes - October 91-November 92. 9 July 1990.

_ . "Committee assignments for 1991." Memo to FGG Board Members. SFPL, GLC 27, Box - FGG Business 82-94, File: Big Red Binder. 15 February 1991.

Forzley, Richard and Hughes, Douglas, eds. (1990). The Spirit Captured: The Official Photojournal of Celebration' 90 - Gay Games III \& Cultural Festival. Vancouver, BC: For Eyes Press, 1990.

Gay, Peter, ed. The Freud Reader. New York: W.W. Norton \& Company, 1989.

Leader, Darien, and Groves, Judy. Lacan for Beginners. Cambridge: Icon, 1995.

"Letter from Australia". SFPL, GLC 27, GG III - Unprocessed Box for Series III - Mail Out 1988. December 1988.

Mandel, Bill. "How Olympic foes hurt Tom Waddell's memory." San Francisco Chronicle 30 March 1988: A5.

- "With the death of Tom Waddell, a child loses her dad and S.F. loses one of its best." San Francisco Chronicle 12 July 1987: B3.

Marcus, Mr. "Warren Cave, Dr. Tom Waddell Men of the Year." $B A R$ 5 March 1987: 32.

McDell, Barry. "Waddell's dream of an international Gay Games is fulfilled." Celebration '90: Newsletter of Gay Games III and Cultural Festival June 1989: 4. SFPL, GLC 27, Box - Vancouver - Integrate into Series III, File: Celebration '90 - Fundraising/ Business Backer.

Miller, Toby. "Scouting for boys: Sport looks at men." Tourism, leisure, sport: Critical perspectives. Eds. D. Rowe \& G. Lawrence. Rydalmere, NSW: Hodder Education, 1998. 194-203. 
Moor, Paul. "Gay Olympian in his own words." San Francisco Chronicle 13 July 1987: 41.

MVAAA Board of Directors. Meeting minutes. SFPL, GLC 27, Box - Integrate into Series III Material, File: MVAAA Meeting Minutes. 9 April 1989.

New York in '94. "Games can change the world: Unity 94." Corporate fundraising information package. SFPL, GLC 27, Box - Derek GGIV NYC 1994, File - Big Blue Binder. 1993.

Newquist, Jay. "Gay Games promoter Zohn Artman dies." BAR 2 October 1987: 18.

Neyts, Rob. "The Tom Waddell Trophy Transfer, Insurance, and Shipping Requirements." Letter to FGG Co-Presidents. SFPL, GLC 27, Box - FGG Business 82-94, File - Federation Board Information and Minutes October 91-November 92. 2 May 1991.

Opening \& Closing Ceremonies. The Games Guide: The Official Guide to all Gay Games IV and Cultural Festival Events. SFPL, GLC 27, Box - Derek GG IV 1994 NYC. 1994, 44

Opening Ceremonies - Gay Games IV. Official Program. SFPL, GLC

27, Box -Derek GG IV 1994 NYC. 18 June 1994.

"Personal trophy project." Celebration '90: Newsletter of Gay Games III and Cultural Festival. Vancouver, BC: MVAAA. SFPL, GLC 27, Series III, Box 3 - Games Clippings, File: Folder \#4. November-December, 1988.

Peterson, Rick. \& Kennedy, Susan. Letter to FGG Board. SFPL, GLC 27, Box - FGG Business 82-94, Derek's Red Binder - FGG 1989 thru 1994. 4 April, 1994.

"Photo file." SFPL, GLC 27, Box - GGV 98 RoseMary Mitchell Material, FilE Photos. 1998.

Probyn, Elspeth. "Sporting bodies: Dynamics of shame and pride." Body \& Society, 6 (2000): 13-28.

Repa, Barbara Kate. (1987, June 26). "No Gay Olympics, high court says." San Francisco Chronicle 26 June 1987: A1, A20.

Ross, B. "Rikki Streicher" Editorial. BAR 25 August 1994: 6. "A salute to Tom Waddell." Photograph. BAR 2 July 1987: 14. Schaap, Dick. "Death of an athlete." Sports Illustrated 27 July 1987: 26-32. SFPL, GLC 27, Series IV, Box 8, Folder 3: Information Pack. 
. "Sports commentator makes his plans for New York in '94." Unity '94: The official sponsorship newsletter of the 1994 Gay Games, 1 (Spring 1991): 1,4. SFPL, GLC 27, Box - Derek GG IV NYC 1994.

Scheer, Robert. "Decathlon champion's final hurdle." San Francisco Chronicle 24 October 1986: 33.

SFAA Board of Directors. Meeting minutes. SFPL, GLC 27, Box 1, Series I, Folder: 1982 Gay Olympic Games. 3 March 1986.

- Meeting Minutes. SFPL, GLC 27, Assorted Box Unprocessed - Box \#3 - Games Clippings From Rosemary Mitchell. 6 April 1988.

"They stole a word." BAR 5 November, 1987: 6.

“Tom Waddell dead at age 49, founder of S.F.'s Gay Games." San Francisco Chronicle 12 July 1987: B1.

“Tom Waddell Trophy." Celebration'90: Gay Games III \& Cultural Festival, 7. Official Program. Vancouver, BC: MVAAA. Gay and Lesbian Historical Society of Northern California Archives, Box - Gay Games, File: GG III Ephemera. 1990.

Waddell, Tom. "Update '82 Olympics: The good news is..." BAR 11 February 1982: 25.

— \& Schaap, Dick. Gay Olympian: The Life and Death of Dr. Tom Waddell. New York: Alfred A. Knopf, 1996.

Weiss, P. “Olympian comes out." Unity '94: The official sponsorship newsletter of the 1994 Gay Games, 1 (Spring 1991): 1, 4. SFPL, GLC 27, Box - Derek GG IV NYC 1994.

White, Allen. "AIDS claims Olympian Waddell: Gay Games organizer honored by city." BAR 16 July 1987a: $1,23$.

- "Hundreds mourn Tom Waddell in City Hall service." BAR 23 July 1987b: 13.

Zizek, Slavoj. The Sublime Object of Ideology. London: Verso, 1989. Zwicker, Heather. "Hometown pride." Vue Weekly: Edmonton's 100\% Independent News and Entertainment Weekly - Pride Issue 2002, 347 (13-19 June 2002): 11, 14. 